\title{
Preparation of Isodehydrodigallic Acid Using Ullmann Condensation
}

\author{
Haruka Imai, ${ }^{a}$ Ryo Koyama, ${ }^{b}$ Yoshikazu Horino, ${ }^{b}$ and Hitoshi Abe ${ }^{*, b}$ \\ ${ }^{a}$ Graduate School of Innovative Life Science, University of Toyama; Toyama 930-8555, Japan: and ${ }^{b}$ Faculty of \\ Engineering, University of Toyama; Toyama 930-8555, Japan. \\ Received November 20, 2020; accepted December 21, 2020
}

Isodehydrodigallic acid, which is an important component of several ellagitannin compounds, was easily synthesized using a classical Ullmann condensation reaction.

Key words diaryl ether; Ullmann condensation; ellagitannin; copper

\section{Introduction}

Several types of polyphenolic compound have been isolated from higher plants, and their chemical structures have been elucidated using NMR techniques. ${ }^{1)}$ Among them, ellagitannin compounds can be isolated from the aqueous phase of plant extracts. Ellagitannins display remarkable structural complexity, involving glucose moieties and gallic acid (1) derivatives. Furthermore, ellagitannins exhibit diverse and valuable biological properties, such as antioxidant, ${ }^{2-4)}$ antitumor, ${ }^{5-7)}$ antimicrobial, ${ }^{8)}$ and antiviral ${ }^{9,10)}$ activities. The yields of ellagitannins are low when they are extracted from natural sources; methods for chemical synthesis of ellagitannins and related compounds should therefore be developed.

The structures of several ellagitannin compounds contain either $\mathrm{C}-\mathrm{C}$ or $\mathrm{C}-\mathrm{O}-\mathrm{C}$ bonds connecting the aromatic rings of two gallic acid moieties. Hexahydroxydiphenoyl (HHDP) and dehydrodigalloyl (DHDG) groups are commonly found in ellagitannin molecules. Isodehydrodigalloyl (isoDHDG), ${ }^{11-13)}$ which has a tetra-ortho-substituted diaryl ether structure, is also found in naturally occurring ellagitannins. An example of a natural product containing the isoDHDG group is isochestanin, which was previously isolated from Castanea mollissima (Feng et al.). Isodehydrodigallic acid was identified as a hydrolyzation product of isochestanin ${ }^{14)}$ (Chart 1).

To synthesize tetra-ortho-substituted diaryl ether, a process for synthetic $\mathrm{C}-\mathrm{O}-\mathrm{C}$ bond formation between two aromatic rings that is capable of overcoming steric hindrance must be established. Several reports have presented methods for preparing sterically hindered diaryl ether. ${ }^{15-17)}$ Synthesis of diaryl ether derived from gallic acid using Ullmann condensation was reported. ${ }^{18)}$ However, the desired diaryl ether was only obtained in 33\% yield in this method. On the other hand, we explored for the condition of classical Ullmann condensation ${ }^{19}$ ) and established a simple method for diaryl ether synthesis, in which diaryl ether (5) was synthesized from phenol (3) and bromide (4) using copper powder. Moreover, after a two-step conversion process, dehydrodigallic acid (6) was formed ${ }^{20)}$ (Chart 2). In the present study, we applied a similar method to synthesize isodehydrodigallic acid (2) which possesses sterically more hindered property. Steric hindrance had to be overcome at the key reactive positions; thus, this article describes the preparation of the phenol (7) and bromide (8) compound precursors, as well as the key Ullmann condensation reaction for the synthesis of isodehydrodigallic acid (2) (Chart 2).

\section{Results and Discussion}

We first generated the phenol compound required to synthesize the desired diaryl ether. A phenolic hydroxyl group at the 4-position of methyl gallate (10) was protected with a methoxymethyl (MOM) group to obtain compound 11. Then, the remaining phenolic hydroxy groups at the 3- and 5-positions of $\mathbf{1 1}$ were protected with benzyl groups to form 12, followed by deprotection of the MOM group with aqueous $\mathrm{HCl}$ to produce 13 . We then synthesized the coupling partner, bromide 4, from methyl gallate (10) via a two-step process by the reported procedure. ${ }^{20)}$ Following the preparation of compounds 13 and $\mathbf{4}$, we conducted the Ullmann condensation reaction under the following conditions: copper (6.0 equivalent (eq.)) and $N, N$-dimethylacetamide (DMA) at $160^{\circ} \mathrm{C}$ for $1 \mathrm{~h}$. We obtained a $76 \%$ yield of the desired ether compound $\mathbf{1 4}$, as well as $52 \%$ of debrominated compound $\mathbf{4}$ and a small amount of dimerized compound $\mathbf{4}$ as a by-product. Finally, a two-step
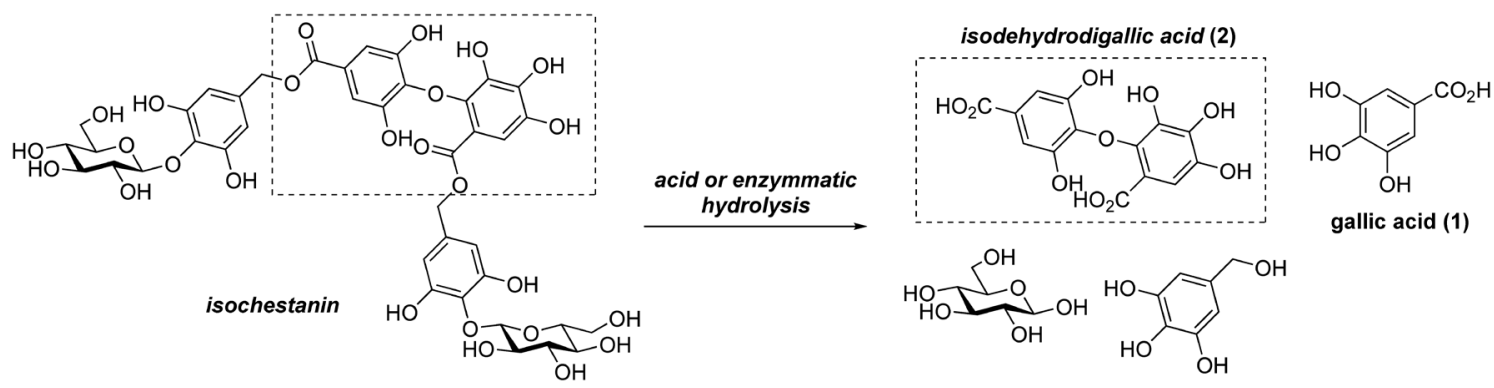

Chart 1. Diaryl Ether Component Containing in Natural Products 

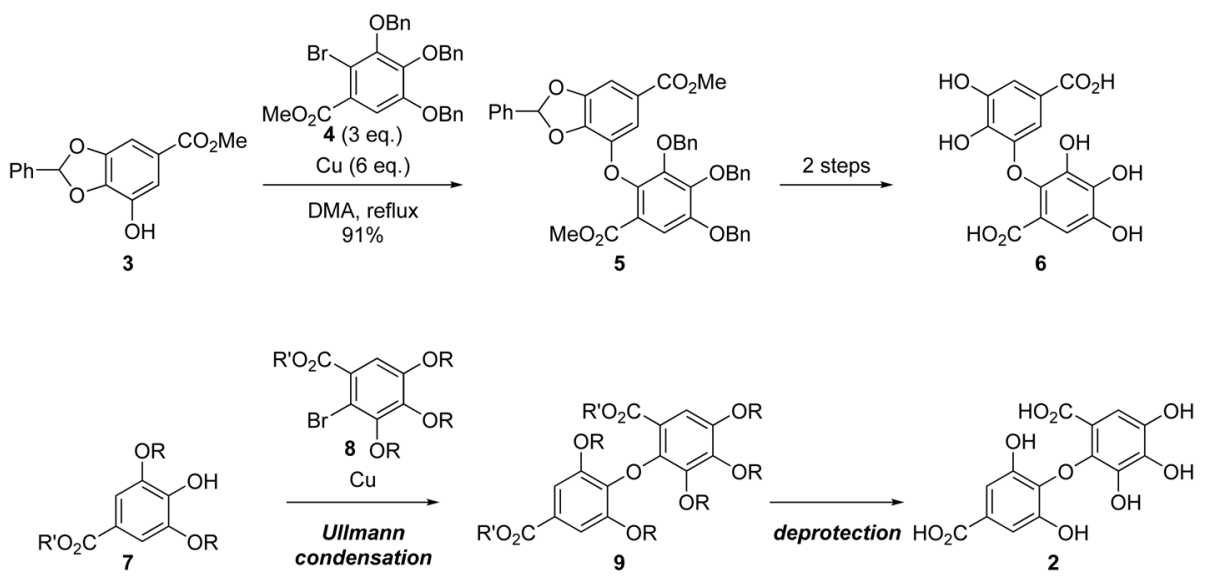

Chart 2. The Approach for Highly Functionalized Diaryl Ether Using Ullmann Condensation
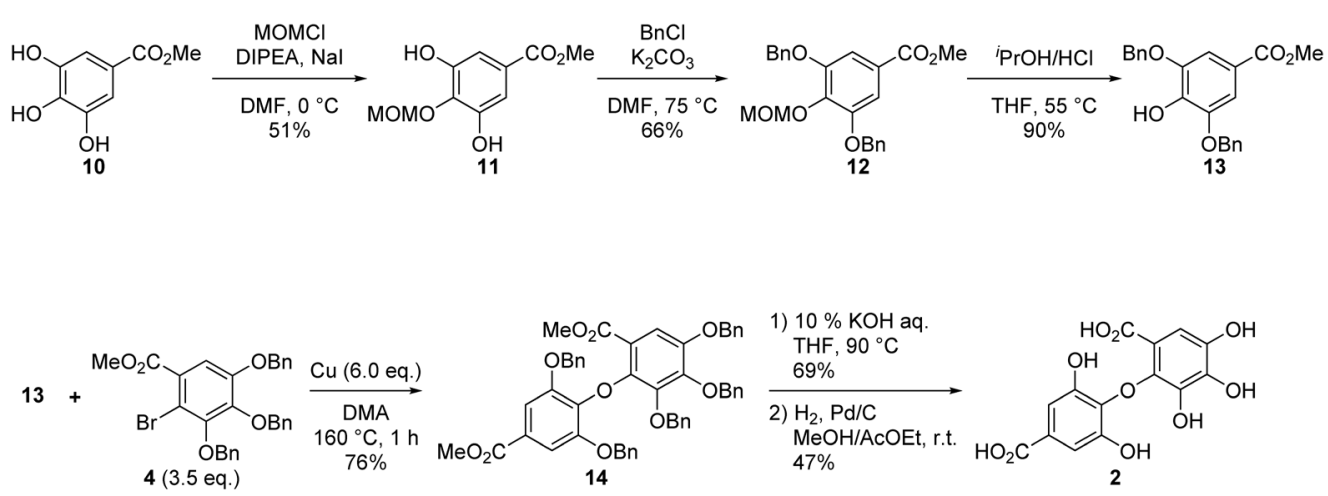

Chart 3. Synthetic Route of Isodehydrodigallic Acid (2) from Methyl Gallate (10)

process involving saponification and hydrogenolysis concluded the synthesis of isodehydrodigallic acid (2) (Chart 3).

In this study, we chemically synthesized isodehydrodigallic acid using the Ullmann condensation reaction, and demonstrated its effectiveness for synthesizing sterically hindered diphenyl ethers.

\section{Experimental}

General Information The melting points of each compound were measured using a Yanagimoto micro-melting point hot-plate. IR spectra were recorded using a Shimadzu FTIR-8400 spectrophotometer. NMR spectra were obtained using a JEOL $\alpha-400(400 \mathrm{MHz})$ instrument. Chemical shifts were expressed in $\delta$ parts per million ( $\mathrm{ppm}$ ), with tetramethylsilane (TMS) as an internal standard. Elemental analyses were performed using an Elementar vario MICRO cube. The electron impact (EI)MS analysis was performed using the JMSAX505HAD instrument (JEOL, Tokyo, Japan). Silica gel column chromatography was carried out using Wakogel ${ }^{\circledR}$ C-200 or $60 \mathrm{~N}$ as the stationary phase. TLC analysis was performed on Silicagel $70 \mathrm{~F}_{254}$ (Wako, Osaka, Japan) plates. Solvents were dried using a standard procedure.

Methyl 3,5-Dihydroxy-4-methoxymethylbenzoate (11) A solution containing compound $\mathbf{1 0}(5.00 \mathrm{~g}, 27.2 \mathrm{mmol}), \mathrm{N}, \mathrm{N}$ dimethylformamide (DMF) $(100 \mathrm{~mL})$, diisopropylethylamine (DIPEA) $(5.68 \mathrm{~mL}, 27.2 \mathrm{mmol})$ and $\mathrm{NaI}(4.07 \mathrm{~g}, 27.2 \mathrm{mmol})$ was stirred for $30 \mathrm{~min}$ at $0^{\circ} \mathrm{C}$. $\mathrm{MOMCl}(2.06 \mathrm{~mL}, 32.6 \mathrm{mmol})$ was then added to the solution and stirred for $10 \mathrm{~min}$ at the same temperature. The mixture was neutralized by addition of sat. aq $\mathrm{NH}_{4} \mathrm{Cl}$ and the resulting mixture was then extracted using ethyl acetate (AcOEt). The organic layer was washed with brine, dried over $\mathrm{MgSO}_{4}$, and then evaporated to yield a crude residue. The residue was recrystallized from AcOEt to generate a colorless solid of 11 (3.03 g, 51\%). mp $126.0-129.0^{\circ} \mathrm{C}$ (AcOEt). IR (KBr): $v_{\max } 3300,2955,1904$, $1678,1281,773 \mathrm{~cm}^{-1}$. ${ }^{1} \mathrm{H}-\mathrm{NMR}\left(400 \mathrm{MHz}, \mathrm{CDCl}_{3}\right) \delta: 7.21(1 \mathrm{H}$, s, Ph), $6.76(1 \mathrm{H}, \mathrm{s}, \mathrm{Ph}), 5.14\left(2 \mathrm{H}, \mathrm{s}, \mathrm{CH}_{2}\right), 3.88\left(3 \mathrm{H}, \mathrm{s}, \mathrm{CH}_{3}\right)$, $3.72\left(3 \mathrm{H}, \mathrm{s}, \mathrm{CH}_{3}\right) .{ }^{13} \mathrm{C}-\mathrm{NMR}\left(100 \mathrm{MHz}, \mathrm{CDCl}_{3}\right) \delta: 166.5,148.2$, 137.3, 127.0, 109.8, 99.2, 57.6, 52.2. Anal. Calcd for $\mathrm{C}_{10} \mathrm{H}_{12} \mathrm{O}_{6}$ : C, 52.64; H, 5.30. Found: C, 52.67; H, 5.27.

Methyl 3,5-Dibenzyloxy-4-methoxymethylbenzoate (12) A solution containing compound $11(1.4 \mathrm{~g}, 6.05 \mathrm{mmol}), \mathrm{K}_{2} \mathrm{CO}_{3}$ $(3.0 \mathrm{~g}, 21.8 \mathrm{mmol})$ and DMF $(14 \mathrm{~mL})$ was stirred for $30 \mathrm{~min}$ at room temperature. benzyl chloride $(1.6 \mathrm{~mL}, 13.9 \mathrm{mmol})$ was added to the solution and stirred for $4 \mathrm{~h}$ at room temperature. The mixture was acidified by addition of $10 \% \mathrm{HCl}$ (aq), and then poured into water and extracted using AcOEt. The organic layer was washed with brine, dried over $\mathrm{MgSO}_{4}$, and then evaporated to yield a crude residue. The residue was recrystallized from AcOEt to generate a colorless solid of $\mathbf{1 2}(1.6 \mathrm{~g}$, $66 \%$ ). mp 104.3-105.2 ${ }^{\circ} \mathrm{C}$ (AcOEt). IR (KBr) $v_{\max } 2951,2886$, $1716,1261,757 \mathrm{~cm}^{-1} .{ }^{1} \mathrm{H}-\mathrm{NMR}\left(400 \mathrm{MHz}, \mathrm{CDCl}_{3}\right) \delta: 7.46-7.30$ $(12 \mathrm{H}, \mathrm{m}, \mathrm{Ph}), 5.20\left(2 \mathrm{H}, \mathrm{s}, \mathrm{CH}_{2}\right), 5.14\left(4 \mathrm{H}, \mathrm{s}, \mathrm{PhCH}_{2} \times 2\right), 3.89$ $\left(3 \mathrm{H}, \mathrm{s}, \mathrm{CH}_{3}\right), 3.47\left(3 \mathrm{H}, \mathrm{s}, \mathrm{CH}_{3}\right) \cdot{ }^{13} \mathrm{C}-\mathrm{NMR}\left(100 \mathrm{MHz}, \mathrm{CDCl}_{3}\right)$ 
$\delta: 166.5,152.3,139.8,136.4,128.5,128.1,127.6,125.5,108.6$ 98.3, 71.1, 57.2, 52.2. Anal. Calcd for $\mathrm{C}_{24} \mathrm{H}_{24} \mathrm{O}_{6}: \mathrm{C}, 70.58 ; \mathrm{H}$, 5.92. Found: C, 70.45; H, 5.97.

Methyl 3,5-Dibenzyloxy-4-hydroxybenzoate (13) A solution containing $12(1.5 \mathrm{~g}, 3.72 \mathrm{mmol})$ and tetrahydrofuran (THF) $(11 \mathrm{~mL})$ was stirred for $30 \mathrm{~min}$ at room temperature. A mixture of ${ }^{i} \mathrm{PrOH}$ and conc. $\mathrm{HCl}(\mathrm{v} / \mathrm{v}=50 / 1,33 \mathrm{~mL})$ was added to the solution, which was stirred for $1.5 \mathrm{~h}$ at $55^{\circ} \mathrm{C}$. The mixture was cooled to room temperature and $\mathrm{NaHCO}_{3}$ (aq) was added. The mixture was then poured into water and extracted using AcOEt. The organic layer was washed with brine, dried over $\mathrm{MgSO}_{4}$, and evaporated to yield a crude residue. The residue was recrystallized from AcOEt to generate a colorless solid of $\mathbf{1 3}(1.2 \mathrm{~g}, 90 \%)$. mp $133.2-134.5^{\circ} \mathrm{C}$ (AcOEt). IR (KBr): $v_{\max } 3438.8,2954.7,2874.7,1699.2,746.4 \mathrm{~cm}^{-1}$. ${ }^{1} \mathrm{H}-\mathrm{NMR}\left(400 \mathrm{MHz}, \mathrm{CDCl}_{3}\right) \delta: 7.46-7.33(12 \mathrm{H}, \mathrm{m}, \mathrm{Ph}), 5.94$ $(1 \mathrm{H}, \mathrm{s}, \mathrm{OH}), 5.18\left(4 \mathrm{H}, \mathrm{s}, \mathrm{PhCH}_{2} \times 2\right), 3.87\left(3 \mathrm{H}, \mathrm{s}, \mathrm{CH}_{3}\right)$. ${ }^{13} \mathrm{C}-\mathrm{NMR}\left(100 \mathrm{MHz}, \mathrm{CDCl}_{3}\right) \delta: 166.7,145.9,140.2,136.2$, 128.6, 128.3, 127.8, 120.9, 108.7, 71.4, 52.1. Anal. Calcd for $\mathrm{C}_{22} \mathrm{H}_{20} \mathrm{O}_{5}$ : C, 72.52; H, 5.53. Found: C, 72.42; H, 5.50.

Methyl 3,4,5-Tri(benzyloxy)-2-(2,6-(benzyloxy)-4-(methoxycarbonyl)phenoxy) Benzoate (14) The flask was charged with 13 (100 mg, $0.274 \mathrm{mmol}), 4$ (512 $\mathrm{mg}, 0.960 \mathrm{mmol}), \mathrm{Cu}$ $(105 \mathrm{mg}, 1.65 \mathrm{mmol})$, and DMA $(0.7 \mathrm{~mL})$. The resulting mixture was stirred under $\mathrm{N}_{2}$ at $160^{\circ} \mathrm{C}$ for $1 \mathrm{~h}$, and then cooled to room temperature, filtered, and washed with AcOEt. The mixture was acidified by adding $10 \% \mathrm{HCl}(\mathrm{aq})$, and then poured into water and extracted with AcOEt. The organic layer was washed with brine and dried over $\mathrm{MgSO}_{4}$. A residue formed following evaporation, which was purified using silica gel column chromatography $\left(\mathrm{CH}_{2} \mathrm{Cl}_{2} /\right.$ hexane/EtOAc $\left.=1: 1: 0.25\right)$ to generate a yellow oil of $\mathbf{1 4}(170 \mathrm{mg}, 76 \%)$. IR (neat): $v_{\max }$ 3028, 2950, 1716, 1590, 1434, 1336, 1213,1113, 747, $703 \mathrm{~cm}^{-1}$. ${ }^{1} \mathrm{H}-\mathrm{NMR}\left(400 \mathrm{MHz}, \mathrm{CDCl}_{3}\right) \quad \delta: 7.45-7.12(28 \mathrm{H}, \mathrm{m}, \mathrm{ArH})$, $4.99\left(2 \mathrm{H}, \mathrm{s}, \mathrm{CH}_{2}\right), 4.92\left(4 \mathrm{H}, \mathrm{br}, \mathrm{CH}_{2}\right), 4.86\left(2 \mathrm{H}, \mathrm{s}, \mathrm{CH}_{2}\right), 4.83$ $\left(2 \mathrm{H}, \mathrm{s}, \mathrm{CH}_{2}\right), 3.90\left(3 \mathrm{H}, \mathrm{s}, \mathrm{CH}_{3}\right), 3.70\left(3 \mathrm{H}, \mathrm{s}, \mathrm{CH}_{3}\right) .{ }^{13} \mathrm{C}-\mathrm{NMR}$ $\left(100 \mathrm{MHz}, \mathrm{CDCl}_{3}\right) \delta: 166.6,165.9,149.4,147.9,146.7,144.8$, $141.1,137.2,137.1,136.6,136.4,128.5,128.2,128.0,127.5$, 127.4, 117.6, 110.2, 109.1, 75.3, 75.1, 71.2, 71.1, 52.1, 52.0. High resolution (HR)MS-EI $(\mathrm{m} / \mathrm{z})$ : Calcd for $\mathrm{C}_{51} \mathrm{H}_{44} \mathrm{O}_{10}[\mathrm{M}]^{+}$ 816.2934; Found, 816.2929.

2-(2,6-Benzyloxy-4-carbaxyphenoxy)-3,4,5-tribenzyloxybenzoic Acid (15) A solution containing compound 14 (166 mg, $0.203 \mathrm{mmol})$ and THF $(15 \mathrm{~mL})$ was stirred for $30 \mathrm{~min}$ at room temperature. Then, $10 \mathrm{~mL}$ of $10 \% \mathrm{KOH}$ (aq) was added to the solution and stirred for $48 \mathrm{~h}$ at room temperature. $\mathrm{NaHCO}_{3}$ (aq) was then added to the mixture, which was poured into water and extracted with AcOEt. The organic layer was washed with brine, dried over $\mathrm{MgSO}_{4}$, and evaporated to give a residue which was recrystallized from $\mathrm{CH}_{2} \mathrm{Cl}_{2}$. A white solid of $\mathbf{1 5}(110 \mathrm{mg}, 69 \%)$ was generated. $\mathrm{mp}$ $185.0-187.5^{\circ} \mathrm{C}\left(\mathrm{CH}_{2} \mathrm{Cl}_{2}\right)$. IR (KBr): $v_{\max } 1684,1433,1113,733$, $696 \mathrm{~cm}^{-1}$. ${ }^{1} \mathrm{H}-\mathrm{NMR}\left(400 \mathrm{MHz}, \mathrm{CDCl}_{3}\right) \delta: 7.45-6.85(28 \mathrm{H}, \mathrm{m}$, ArH), $5.06\left(2 \mathrm{H}, \mathrm{s}, \mathrm{CH}_{2}\right), 4.98\left(2 \mathrm{H}, \mathrm{s}, \mathrm{CH}_{2}\right), 4.92\left(2 \mathrm{H}, \mathrm{br}, \mathrm{CH}_{2}\right)$, $4.77\left(2 \mathrm{H}\right.$, br, $\left.\mathrm{CH}_{2}\right), 4.67\left(2 \mathrm{H}, \mathrm{s}, \mathrm{CH}_{2}\right) .{ }^{13} \mathrm{C}-\mathrm{NMR}(100 \mathrm{MHz}$, $\left.\mathrm{CDCl}_{3}\right) \delta: 171.1,166.9,150.1,148.5,146.8,146.2,143.9,140.2$, $136.8,136.6,136.3,135.6,128.6,128.5,128.4,127.8,127.7$, 116.1, 110.6, 108.8, 75.4, 74.9, 71.1, 70.9. Anal. Calcd for $\mathrm{C}_{49} \mathrm{H}_{40} \mathrm{O}_{10}:$ C, 74.61; H, 5.11. Found: C, 74.58; H, 5.08.

Isodehydrodigallic Acid (2) A solution containing compound 15 (400 mg, $0.507 \mathrm{mmol})$ and methanol $(\mathrm{MeOH}) / \mathrm{AcOEt}$
$(1: 1,16 \mathrm{~mL})$ was stirred at room temperature. Then, $10 \% \mathrm{Pd} / \mathrm{C}$ $(40 \mathrm{mg})$ was added to the solution and stirred for $1.5 \mathrm{~h}$ at room temperature. The reaction mixture was filtered and washed with $\mathrm{MeOH} / \mathrm{AcOEt}$, and the organic layer was then evaporated to give a residue which was recrystallized from $\mathrm{H}_{2} \mathrm{O}$, resulting in a colorless solid of 2 (81 mg, 47\%). mp $199.0-200.0^{\circ} \mathrm{C}$ $\left(\mathrm{H}_{2} \mathrm{O}\right)$. IR (KBr): $v_{\max } 3246,2525,1690,1607,1348,1262$, $729 \mathrm{~cm}^{-1}$. ${ }^{1} \mathrm{H}-\mathrm{NMR}\left(400 \mathrm{MHz}\right.$, acetone- $\left.d_{6}+\mathrm{D}_{2} \mathrm{O}\right) \delta: 7.10(2 \mathrm{H}$, $\mathrm{s}, \mathrm{ArH}), 6.97(1 \mathrm{H}, \mathrm{s}, \mathrm{ArH}) .{ }^{13} \mathrm{C}-\mathrm{NMR}(100 \mathrm{MHz}$, acetone$\left.d_{6}+\mathrm{D}_{2} \mathrm{O}\right)^{21)} \delta: 170.6,167.7,150.6,142.3,139.9,139.6,139.2$, 138.6, 127.5, 114.5, 110.5, 108.2. Anal. Calcd for $\mathrm{C}_{14} \mathrm{H}_{10} \mathrm{O}_{10}: \mathrm{C}$, 49.72; H, 3.19. Found: C, 49.55; H, 2.93.

Acknowledgments A part of this study was financially supported by THE HOKURIKU BANK Grant-in-Aid for Young Scientists for $\mathrm{H}$. A.

Conflict of Interest The authors declare no conflict of interest.

Supplementary Materials The online version of this article contains supplementary materials.

\section{References and Notes}

1) "Chemistry and Biology of Ellagitannins. An Underestimated Class of Bioactive Plant Polyphenols," ed. by Quideau S., World Scientific Publishing Co., Pte. Ltd., Singapore, 2009.

2) Atta-Ur-Rahman, Ngounou F. N., Choudhary M. I., Malik S., Makhmoor T., Nur-E-Alam M., Zareen S., Lontsi D., Ayafor J. F. Sondengam B. L., Planta Med., 67, 335-339 (2001).

3) Bagch D., Hassoun E. A., Bagchi M., Stohs S. J., Free Radic. Biol. Med., 15, 217-222 (1993)

4) Halvorsen B. L., Holte K., Myhrstrad M. C. W., Barikmo I., Hvattum E., Remberg S. F., Wold A.-R., Haffner K., Baugerød H., Andersen L. F., Moskaug Ø., Jacobs D. R. Jr., Blomhoff R., J. Nutr., 132, 461-471 (2002).

5) Miyamoto K., Kishi N., Koshiura R., Yoshida T., Hatano T., Okuda T., Chem. Pharm. Bull., 35, 814-822 (1987).

6) Miyamoto K., Nomura M., Sasakura M., Matsui E., Koshiura R., Murayama T., Furukawa T., Hatano T., Yoshida T., Okuda T., Jpn. J. Cancer Res., 84, 99-103 (1993).

7) Miyamoto K., Nomura M., Murayama T., Furukawa T., Hatano T., Yoshida T., Koshiura R., Okuda T., Biol. Pharm. Bull., 16, 379-387 (1993).

8) Shiota S., Shimizu M., Mizusima T., Ito H., Hatano T., Yoshida T., Tsuchiya T., FEMS Microbiol. Lett., 185, 135-138 (2000).

9) Fukuchi K., Sakagami H., Okuda T., Hatano T., Tanuma S., Kitajima K., Inoue Y., Inoue S., Ichikawa S., Nonoyama M., Kanno K., Antiviral Res., 11, 285-298 (1989).

10) Nakashima H., Murakami T., Yamamoto N., Sakagami H., Tanuma S., Hatano T., Yoshida T., Okuda T., Antiviral Res., 18, 91-103 (1992).

11) Orabi M. A., Taniguchi S., Hatano T., Phytochemistry, 70, 1286 1293 (2009)

12) Orabi M. A. A., Taniguchi S., Yoshimura M., Hatano T., Heterocycles, 80, 463-475 (2010).

13) Orabi M. A. A., Taniguchi S., Sakagami H., Yoshimura M., Yoshida T., Hatano T., J. Nat. Prod., 76, 947-956 (2013).

14) Feng H., Nonaka G., Nishioka I., Phytochemistry, 27, 1185-1189 (1988).

15) Lin L. H., Ishimatsu M., Tanaka T., Nonaka G., Nishioka I., Chem. Pharm. Bull., 38, 1844-1851 (1990).

16) Feldman K. S., Quideau S., Appel H. M., J. Org. Chem., 61, 66566665 (1996). 
17) Hirokane T., Hirata Y., Ishimoto T., Nishii K., Yamada H., Nat. Commun., 5, 4478 (2014).

18) Mayer W., Fikentscher R., Chem. Ber., 91, 1542-1545 (1958).

19) Fuson R. C., Cleveland E. A., Org. Synth. Coll., III, 339-340 (1955).

20) Shioe K., Ishikura S., Horino Y., Abe H., Chem. Pharm. Bull., 61, 1308-1314 (2013).

21) Some of the NMR chemical shifts do not match between the synthetic and the authentic compounds. For polyphenolic compounds, it is well known that chemical shifts are often moved sensitively by the ratio of mixed solvents. ${ }^{17)}$ In addition, the number of the ${ }^{13} \mathrm{C}$-NMR peaks in the synthetic material is one more than the reported data. We considered that one peak of the quaternary carbon in the authentic data was not detected due to the low resolution of the employed NMR instrument. Totally, we conclude that the data of the synthetic sample is accordant with the data of the authentic material. 